\title{
THE GROWTH OF SOIL FUNGI Penicillium IN THE PRESENCE OF N-(2-pyridylamino)methylenebisphosphonate AS AN ALTERNATIVE SOURCE OF NUTRIENTS
}

\section{WZROST GRZYBÓW GLEBOWYCH RODZAJU Penicillium W OBECNOŚCI KWASU N-(2-pirydyloamino)metylenobisfosfonowego JAKO ALTERNATYWNEGO ŻRÓDŁA POŻYWIENIA}

Independent Department of Biotechnology and Molecular Biology, University of Opole, Poland

\begin{abstract}
Streszczenie. Kwas N-(2-pirydyloamino)metylenobisfosfonowy wykazują dużą aktywność herbicydową. W związku z tym należy zbadać jego odziaływanie na mikroorganizmy glebowe. Celem przeprowadzonych badań była ocena zdolności glebowych szczepów Penicillium do wzrostu w obecności kwasu N-(2-pirydyloamino)metylenobisfosfonowego jako alternatywnego źródła fosforu lub azotu lub węgla. Hodowle grzybów prowadzono w pełnym i zmodyfikowanym mineralnym podłożu Czapek, w temperaturze $25^{\circ} \mathrm{C}$, przez $1-4$ tygodnie. Modyfikacja podłoża polegała na wprowadzeniu $1 \mathrm{mM}$ kwasu $\mathrm{N}$-(2-pirydyloamino)metylenobisfosfonowego jako alternatywnego źródła składników odżywczych. Kontrolę względną stanowił wzrost grzybów w pełnym mineralnym podłożu Czapek, o pH 5,6 i pH 4,0. Kontrolę bezwzględną stanowiły pożywki bez łatwo przyswajalnych składników pokarmowych. Badania obejmowały oznaczenie kinetyki wzrostu grzybów, morfologii grzybów i stopnia rozkładu testowanego kwasu metodą spektrofotometryczną UV-VIS oraz $\mathrm{pH}$ hodowli. Testowane grzyby nie wykorzystywały kwasu $\mathrm{N}$-(2-pirydyloamino)metylenobisfosfonowego jako alternatywnego źródła pożywienia. W każdym z modyfikowanych układów obserwowano zahamowanie wzrostu grzybni; nie odnotowano zmian stężenia wprowadzonego do pożywki kwasu. Równocześnie zaobserwowano zmiany fenotypowe testowanych grzybów, co wskazuje na ich zaburzenia metaboliczne w obecności tego kwasu.
\end{abstract}

Key words: biodegradation, $\mathrm{N}$-(2-pirydylamino)methylenebisphosphonic acid, herbicide, Penicillium. Słowa kluczowe: biodegradacja, kwas N-(2-pirydyloamino)metylenobisfosfonowy, herbicydy, Penicillium.

\section{INTRODUCTION}

Most Penicillium species are considered ubiquitous, opportunistic saprophytes. Fungi of the genus Penicillum are adapted to growth in a variety of environments and on different substrates, including shortage of nutrients (Bujacz et al. 1995; Klimek et al. 2001; Shushkova et al. 2010; Krzyśko-Łupicka and Sudoł 2016). The fungi adaptive capacities include: biosynthesis of enzymes encoded in the mitochondrial genome, introduction of mutation of genome leading to/which leads to changes of constitutive structure of enzymes and mechanisms of their control. 
Enzymatic activity of fungi shows the ability of degrading both organic substances and xenobiotics, which include commonly used pesticides. Most of them are characterized by limited ability to survive in the environment (soil, water) and living organisms due to physicochemical properties, sensitivity to atmospheric agents, processes in or on the soil, and microbial transitions. In living organisms, pesticides undergo biotransformation, which ultimately results in their detoxification, accumulation, or the formation of new compounds that are often more toxic than the starting substrate (Yu and Powles 2014; Tétard-Jones and Edwards 2015). There are many scientific reports on the ability of various microorganisms to use pesticides as a source of energy and nutrients. Among the pesticides, organophosphono compounds are mainly used as insecticides, except glyphosate (N-phosphonomethylglycine), which exhibits herbicidal properties. It is the main ingredient in the commonly used Roundup herbicide. N-(2-pyridylamino)methylenebisphosphonic acid (bisphosphonate) showed higher herbicidal activity than Roundup. It was produced in Japan by Suzuki in 1979 (Lejczak et al. 1996; Forlani et al. 1997; Kafarski et al. 1997; Obojska et al. 2004; Giberti et al. 2017). It is characterized by the presence of covalent C-P bonds resistant to chemical (hydrolytic), thermal or photolytic degradation (Fig. 1).

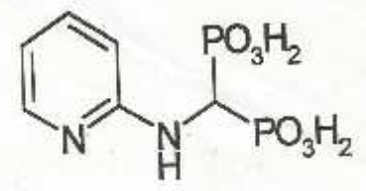

Fig. 1. Chemical structure of $\mathrm{N}$-(2-pyridylamino)methylenebisphosphonic acid Ryc. 1. Wzór strukturalny kwasu N-(2-pirydyloamino)metylenobisfosfonowego

Several mechanisms have been described to date for the utilization of these compounds, and the enzymes involved in these processes have been isolated and described, as well as the genes responsible for the function of these mechanisms. Most described cases have shown that microorganisms are capable of utilizing phosphonates when they are used as the sole source of phosphorus; it is believed that the degradation of compounds containing C-P bonds is catalyzed by C-P lyase. By analogy with phosphonates, soil microorganisms can degrade bisphosphonates (Krzyśko-Łupicka et al. 2002; Krzyśko-Łupicka and Sudoł 2016; Drzyzga et al. 2017). The selection of soil fungi in the presence of the bisphosphonic acid tested allowed the isolation of a group of microorganisms capable of growing in its presence as an alternative source of nutrients. Like glyphosate, it has a selective effect on soil microorganisms, fostering the growth of Fusarium, Verticillium, Penicillium, Aspergillus, Alternaria, Monotospora, Botrytis (Krzyśko-Łupicka 2005) fungi, which can lead to disturbance of biological balance of soils. The strains Aspergillus niger and Fusarium have been tested for their ability to use bisphosphonate as an alternative source of nutrients and biodegradability. The results showed that only Fusarium oxysporum and Cylinrocarpon strains used $\mathrm{N}$-(2-pyridylamino)methylenebisphosphonic acid as an alternative source of phosphorus (Krzyśko-Łupicka et al. 2002; Krzyśko-Łupicka and Sudoł 2016). 
The purpose of the study was to evaluate ability of soil Penicillium strains to grow in the presence of $\mathrm{N}$-(2-pyridylamino)methylenebisphosphonic acid as an alternative source of phosphorus or nitrogen or carbon or nitrogen and phosphorus.

\section{MATERIAL AND METHODS}

The studied material. The three Penicillium strains were chosen for our studies: Penicillium expansum, Penicillium fumiculosum and Penicillum waksmanii. Earlier, these fungi were selected from soil which had been treated by $\mathrm{N}$-(2-pirydylamino)methylenebisphosphonic acid (Krzysko-Lupicka 2005).

This acid used in the study was made in laboratory by prof. Paweł Kafarski from Wroclaw University of Technology.

The N-(2-pirydylamino)methylenebisphosphonic acid (B) was used, in the concentrations of $1.0 \mathrm{mM}$, as a sole source of carbon, or nitrogen, or phosphorus or both nitrogen and phosphorus.

The pure fungal cultures were growing in full $(\mathrm{Cz})$ and mineral modification Czapek medium at $25^{\circ} \mathrm{C}$ through $1-4$ weeks. The medium modification consisted of addition of $1 \mathrm{mM}$ of $\mathrm{N}$-(2-pirydylamino)methylenebisphosphonic acid (B) as an alternative source of following nutriments: carbon $(\mathrm{Cz}-\mathrm{C}+\mathrm{B})$; nitrogen $(\mathrm{Cz}-\mathrm{N}+\mathrm{B})$; phosphorus $(\mathrm{Cz}-\mathrm{P}+\mathrm{B})$ or nitrogen and phosphorus $(\mathrm{Cz}-\mathrm{N}-\mathrm{P}+\mathrm{B})$. The growth of fungi in full mineral $(\mathrm{pH} 5.6)$ as treated as control. Because bisphosphonate acidified the culture medium to $\mathrm{pH} 4.0$ as a control, a full base of mineral capped cap was applied to $\mathrm{pH} 4$.

The growth of fungi in medium without nutrient - carbon $(\mathrm{Cz}-\mathrm{C})$, nitrogen $(\mathrm{Cz}-\mathrm{N})$, phosphorus (Cz-P) or nitrogen and phosphorus (Cz-N-P), was an absolute control.

The fungi population density applied to inoculate the medium was $2 \cdot 10^{6} \mathrm{CFU} \cdot \mathrm{cm}^{-3}$.

After 1, 2, 3 and 4 weeks of culture in following parameters were determined:

$-\mathrm{pH}$

- kinetics of the growth of the studied fungi by determination of mycelium dry mass [g d.m. $\mathrm{dm}^{-3}$ ] at $105^{\circ} \mathrm{C}$;

- a degree of $\mathrm{N}$-(2-pirydylamino)methylenebisphosphonic acid degradation by UV-VIS spectrophotometry following the changes at $\lambda=316 \mathrm{~nm}$;

In parallel, the macro- and microscopic changes of studied fungi, were observed.

Statistical analysis were performed in the R Studio (The R foundation, Austria) and in MS Excell (Microsoft Corporation, USA).

\section{RESULTS}

Most filamentous fungi develop well in the $\mathrm{pH}$ range of 1.5 to 8.5 and at the temperature of $0^{\circ} \mathrm{C}$ to $40^{\circ} \mathrm{C}$. Studied fungi Penicillium expansum, Penicillium fumiculosum and Penicillum waksmanii, behaved differently depending on culture conditions. The effect on growth kinetics and morphology of fungi had both the availability of nutrients and the $\mathrm{pH}$ of the culture (Table 1). In the presence of bisphosphonate, the modified media changed acidity from 3.12 to $3.78 \mathrm{pH}$. During the culture period there were slight changes in the $\mathrm{pH}$ of the media indicating the development of the tested fungi. The largest acidification was observed in medium with alternative source of nitrogen and phosphorus $(\mathrm{Cz}-\mathrm{N}-\mathrm{P}+\mathrm{B})$. 
Table 1. The $\mathrm{pH}$ changes of Penicillium culture in modified medium in incubation time

Tabela 1. Zmiany pH hodowli Penicillium w zmodyfikowanych podłożach w czasie inkubacji

\begin{tabular}{|c|c|c|c|c|c|c|c|c|c|c|c|c|c|}
\hline \multirow{4}{*}{$\begin{array}{c}\text { Modified } \\
\text { medium } \\
\text { Modyfikacja } \\
\text { pożywek }\end{array}$} & \multirow{4}{*}{$\begin{array}{c}\text { Medium } \\
\text { absorbance } \\
\text { Absorpcja } \\
\text { pożywki }\end{array}$} & \multicolumn{12}{|c|}{$\begin{array}{l}\mathrm{pH} \text { of cultures in time incubation } \\
\mathrm{pH} \text { w czasie inkubacji }\end{array}$} \\
\hline & & \multicolumn{4}{|c|}{ P. expansum } & \multicolumn{4}{|c|}{ P. fumiculosum } & \multicolumn{4}{|c|}{ P. waksmanii } \\
\hline & & \multicolumn{4}{|c|}{$\begin{array}{l}\text { incubation time [weeks] } \\
\text { czas inkubacji [tyg.] }\end{array}$} & \multicolumn{4}{|c|}{$\begin{array}{l}\text { incubation time [weeks] } \\
\text { czas inkubacji [tyg.] }\end{array}$} & \multicolumn{4}{|c|}{$\begin{array}{l}\text { incubation time [weeks] } \\
\text { czas inkubacji [tyg.] }\end{array}$} \\
\hline & & 1 & 2 & 3 & 4 & 1 & 2 & 3 & 4 & 1 & 2 & 3 & 4 \\
\hline $\mathrm{Cz}$ pH 5,6 & 5.6 & 6.44 & 6.50 & 6.97 & 7.40 & 4.29 & 4.27 & 6.39 & 7.81 & 6.41 & 5.77 & 5.65 & 8.40 \\
\hline $\mathrm{Cz} \mathrm{pH} 4$ & 4.00 & 5.50 & 4.60 & 3.80 & 4.42 & 4.08 & 3.82 & 4.64 & 7.80 & 6.06 & 6.39 & 6.15 & 7.90 \\
\hline $\mathrm{Cz}-\mathrm{C}$ & 5.14 & 5.25 & 5.17 & 5.51 & 5.34 & 5.32 & 5.33 & 5.08 & 5.30 & 4.24 & 4.50 & 4.25 & 4.30 \\
\hline $\mathrm{Cz}-\mathrm{C}+\mathrm{B}$ & 3.78 & 3.88 & 4.83 & 3.79 & 3.82 & 3.90 & 3.29 & 3.81 & 3.89 & 3.17 & 3.40 & 3.43 & 3.38 \\
\hline $\mathrm{Cz}-\mathrm{N}$ & 5.03 & 4.50 & 3.85 & 4.47 & 4.60 & 4.25 & 4.39 & 4.31 & 4.63 & 3.80 & 4.11 & 4.06 & 3.98 \\
\hline $\mathrm{Cz}-\mathrm{N}+\mathrm{B}$ & 3.38 & 3.37 & 3.37 & 3.36 & 3.35 & 3.41 & 3.38 & 3.34 & 3.34 & 3.23 & 3.39 & 3.39 & 3.37 \\
\hline $\mathrm{Cz}-\mathrm{P}$ & 5.46 & 4.84 & 4.63 & 4.24 & 4.74 & 4.30 & 4.12 & 3.74 & 4.30 & 4.76 & 6.22 & 6.30 & 6.50 \\
\hline $\mathrm{Cz}-\mathrm{P}+\mathrm{B}$ & 3.12 & 3.27 & 3.35 & 3.12 & 3.35 & 3.33 & 3.40 & 3.79 & 3.70 & 3.21 & 3.39 & 3.90 & 3.90 \\
\hline Cz-N-P & 5.64 & 4.58 & 4.35 & 4.17 & 4.34 & 4.29 & 4.29 & 4.23 & 4.75 & 4.25 & 4.55 & 4.13 & 4.25 \\
\hline $\mathrm{Cz}-\mathrm{N}-\mathrm{P}+\mathrm{B}$ & 3.17 & 3.32 & 3.16 & 3.17 & 3.11 & 3.17 & 3.20 & 3.13 & 3.15 & 3.06 & 3.18 & 3.11 & 3.18 \\
\hline
\end{tabular}



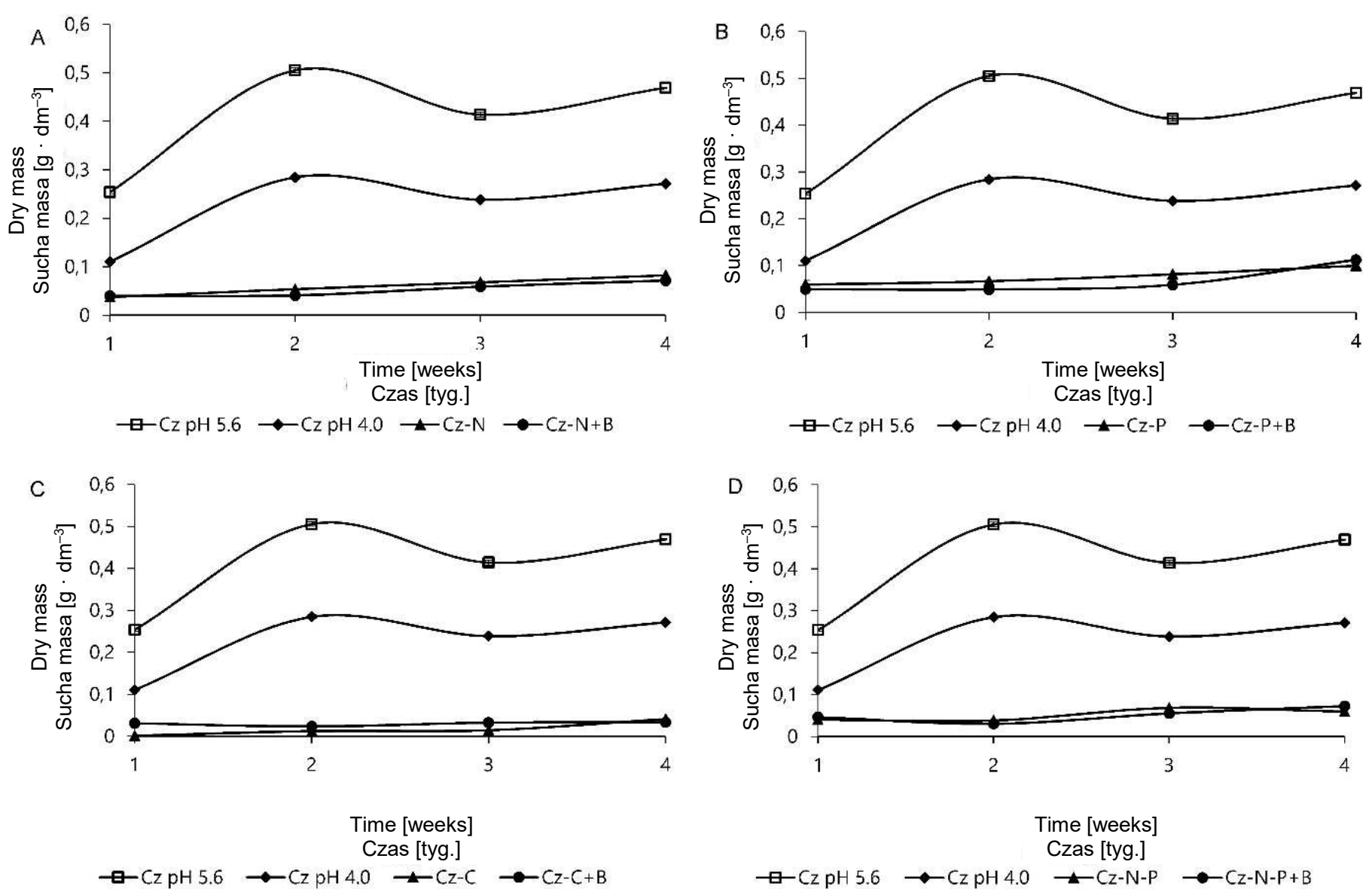

Fig. 2. The kinetics of growth of Penicillium expansum strain in presence of $\mathrm{N}$-(2-pirydyloa-mino)methylenebisphosphonic acid as sole source of: A - nitrogen $(\mathrm{Cz}-\mathrm{N}+\mathrm{B})$, medium without of nitrogen $(\mathrm{Cz}-\mathrm{N})$; B - phosphorus $(\mathrm{Cz}-\mathrm{P}+\mathrm{B})$, medium without of phosphorus $(\mathrm{Cz}-\mathrm{P})$; $\mathrm{C}-\mathrm{carbon}(\mathrm{Cz}-\mathrm{C}+\mathrm{B})$, medium without of carbon $(\mathrm{Cz}-\mathrm{C})$; D - phosphorus and nitogen ( $\mathrm{Cz}-\mathrm{N}-\mathrm{P}+\mathrm{B})$, medium without of phosphorus and nitrogen (Cz-N-P), Czapek medium pH 4 (Cz pH 4), $\mathrm{Czapek} \mathrm{medium} \mathrm{pH} 5.6$ $(\mathrm{Cz} \mathrm{pH}$ 5.6)

Ryc. 2. Kinetyka wzrostu Penicillium expansum w obecności kwasu N-(2-pirydyloamino)metyleno-bisfosfonowego jako alternatywnego źródła: A - azotu $(\mathrm{Cz}-\mathrm{N}+\mathrm{B})$, podłoże bez azotu (Cz-N); B - fosforu (Cz-P+B), podłoże bez fosforu (Cz-P); C - węgla (Cz-C+B), podłoże bez węgla (Cz-C); D - fosforu i azotu (Cz-N-P+B), podłoże bez azotu i fosforu (Cz-N-P), podłoże Czapek pH 4 (Cz pH 4), podłoże Czapek pH 5.6 (Cz pH 5.6) 

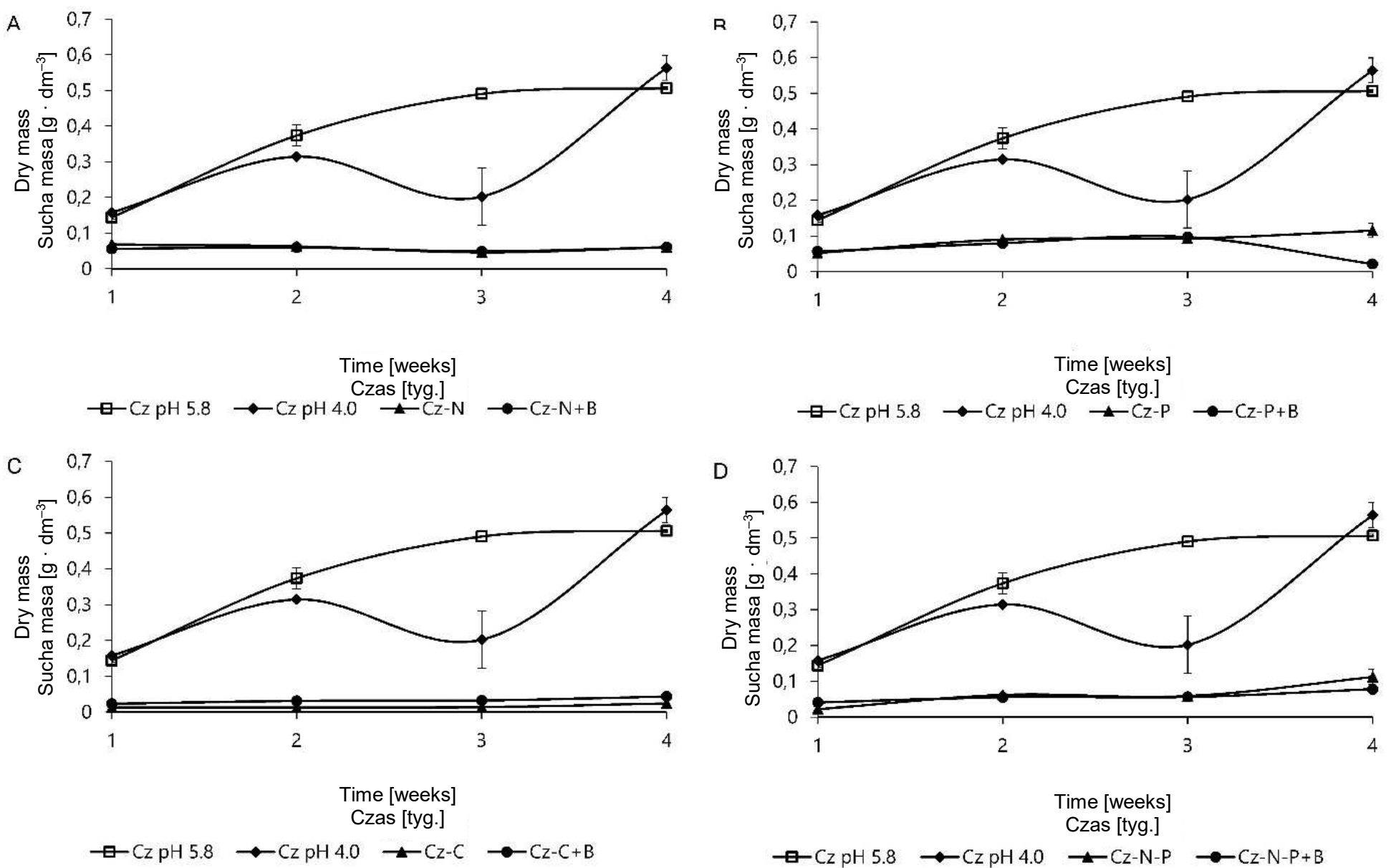

Fig. 3. The kinetics of growth of Penicillium fumiculosum strain in presence of $\mathrm{N}$-(2-pirydyloa-mino)methylenebisphosphonic acid as sole source of: $A-$ nitrogen $(C z-N+B)$, medium without of nitrogen $(C z-N)$; $B-$ phosphorus $(C z-P+B)$, medium without of phosphorus $(C z-P)$; $C-$ carbon $(C z-C+B)$, medium without of carbon (Cz-C); D - phosphorus and nitogen (Cz-N-P+B), medium without of phosphorus and nitrogen (Cz-N-P), Czapek medium pH 4 (Cz pH 4), Czapek medium pH 5.6 (Cz pH 5.6)

Ryc. 3. Kinetyka wzrostu Penicillium fumiculosum w obecności kwasu N-(2-pirydyloamino)metylenobisfosfonowego jako alternatywnego źródła: A - azotu $(\mathrm{Cz}-\mathrm{N}+\mathrm{B})$, podłoże bez azotu (Cz-N); B - fosforu (Cz-P+B), podłoże bez fosforu (Cz-P); C - węgla (Cz-C+B), podłoże bez węgla (Cz-C); D - fosforu i azotu (Cz-N-P+B), podłoże bez azotu i fosforu (Cz-N-P), podłoże Czapek pH 4 (Cz pH 4), podłoże Czapek pH 5.6 (Cz pH 5.6) 

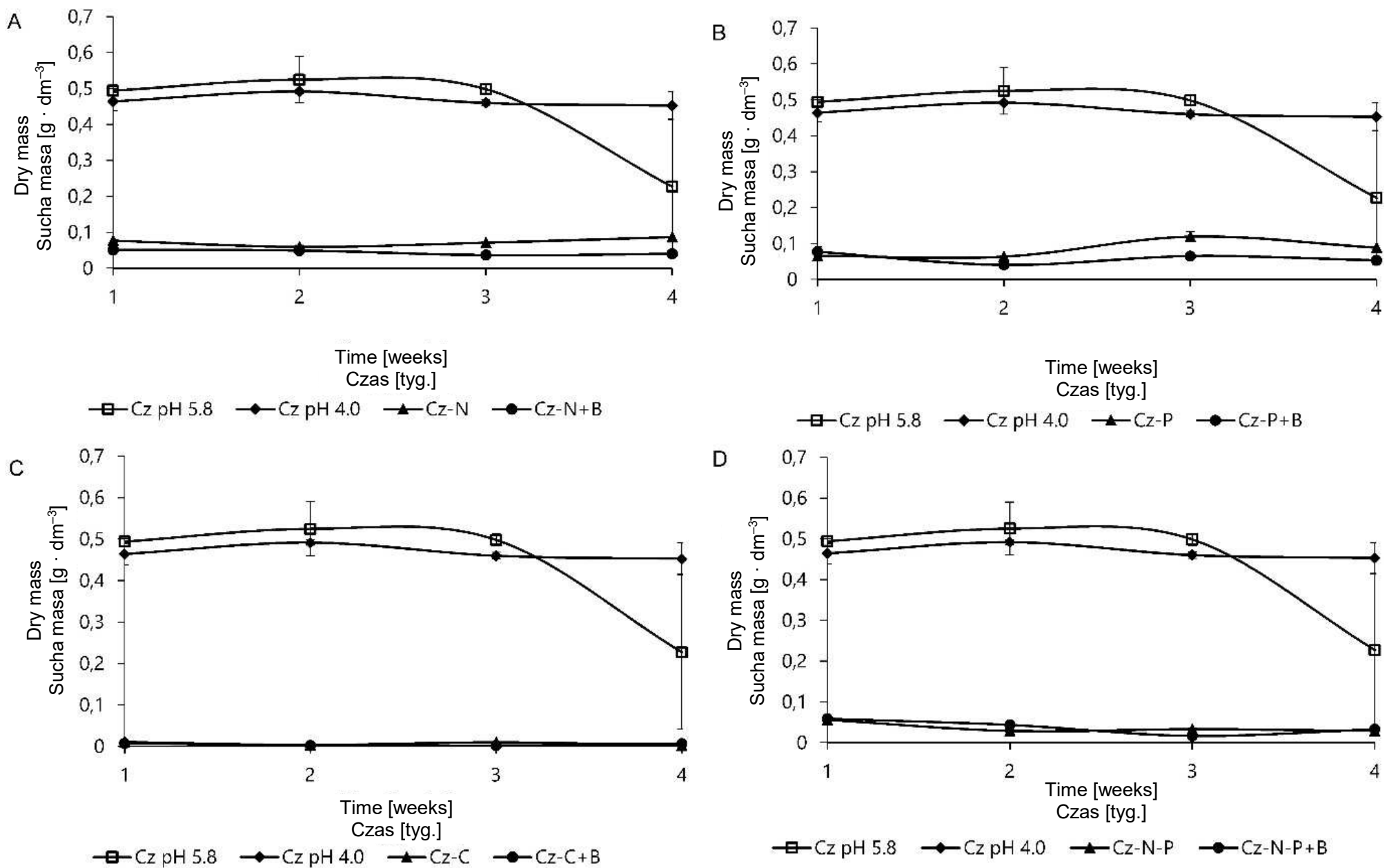

Fig. 4. The kinetics of growth of Penicillum waksmanii strain in presence of $\mathrm{N}$-(2-pirydyloa-mino)methylenebisphosphonic acid as sole source of: $\mathrm{A}-$ nitrogen $(\mathrm{C} z-\mathrm{N}+\mathrm{B})$, medium without of nitrogen $(\mathrm{Cz}-\mathrm{N})$; $\mathrm{B}$ - phosphorus $(\mathrm{Cz}-\mathrm{P}+\mathrm{B})$, medium without of phosphorus $(\mathrm{Cz}-\mathrm{P})$; $\mathrm{C}-$ carbon $(\mathrm{Cz}-\mathrm{C}+\mathrm{B})$, medium without of carbon $(\mathrm{Cz}-\mathrm{C})$; $\mathrm{D}-$ phosphorus and nitogen (Cz-N-P+B), medium without of phosphorus and nitrogen (Cz-N-P), Czapek medium pH 4 (Cz pH 4), Czapek medium pH 5.6 $(\mathrm{Cz} \mathrm{pH}$ 5.6)

Ryc. 4. Kinetyka wzrostu Penicillum waksmanii w obecności kwasu N-(2-pirydyloamino)metyle-nobisfosfonowego jako alternatywnego źródła: A - azotu (Cz-N+B), podłoże bez azotu (Cz-N); B - fosforu (Cz-P+B), podłoże bez fosforu (Cz-P); C - węgla (Cz-C+B), podłoże bez węgla (Cz-C); D - fosforu i azotu (Cz-N-P+B), podłoże bez azotu i fosforu (Cz-N-P), podłoże Czapek pH 4 (Cz pH 4), podłoże Czapek pH 5.6 (Cz pH 5.6) 
Table 2. Spectrofotometric evaluation the level of degradation N-(2-pirydyloamino)methylenebisphosphonic acid as sole source of nutrients by Penicillium strains $[\lambda=316 \mathrm{~nm}]$

Tabela 2 Ocena spektrofotometryczna poziomu degradacji kwasu N-(2-pirydyloamino)metylenobisfosfonowego jako jedynego źródła składników odżywczych przez szczepy Penicillium $[\lambda=316 \mathrm{~nm}]$

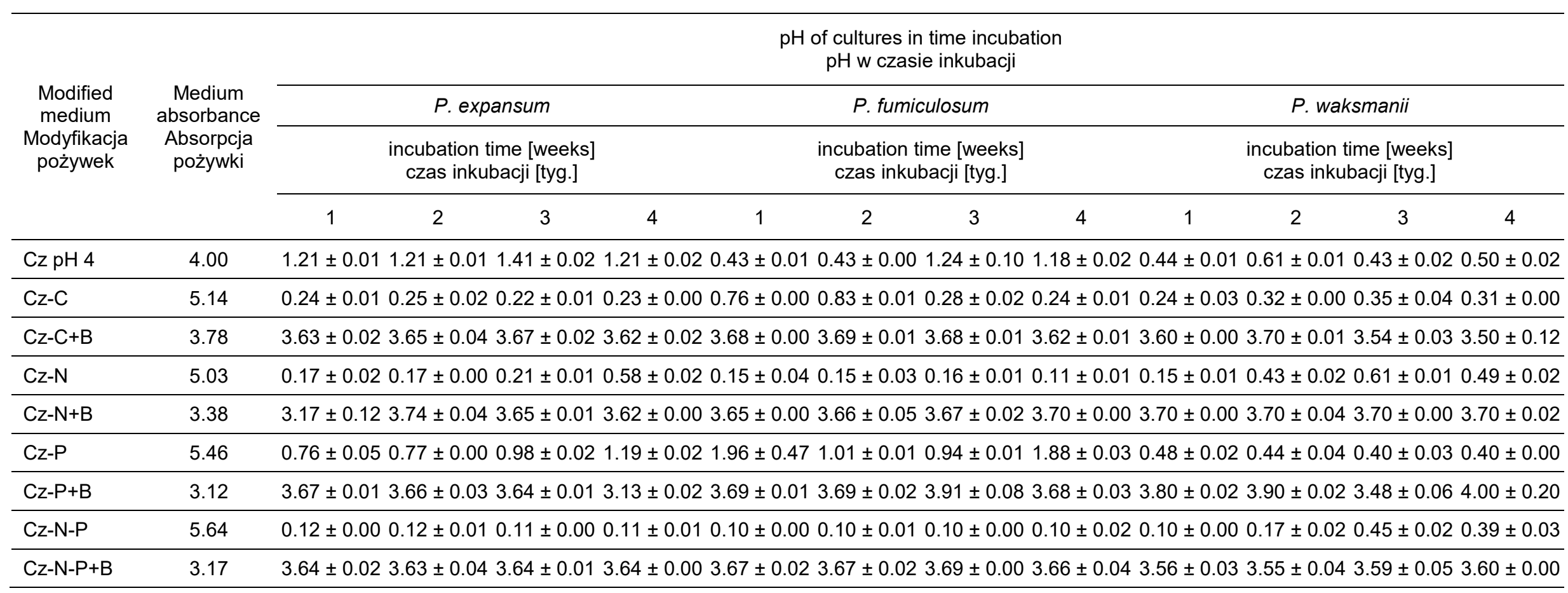


There was no significant increase in mycelium dry weight in the presence of bisphosphonate as an alternative source of nutrients (Fig. 2, 3, 4). This indicates the inability of the tested fungi to use bisphosphonate for growth. Higher increase in dry matter of tested fungi was only observed in whole Czapek medium both at $\mathrm{pH} 5.6$ and $\mathrm{pH} 4.0$.

Parallelly spectrophotometric analyzes did not demonstrate the ability of these fungi to decompose the test compound (Table 2).

It was observed that the availability of nutrients in modified media greatly influenced the phenotypic changes of tested fungi. In the presence of the bisphosphonate as an alternative carbon source, none of the tested strains produced a dye. In contrast, in the presence of bisphosphonate as an alternative source of nitrogen and phosphorus, all Penicillium strains produced a yellow dye that could be treated as a metabolic disorder of the examined fungi in the presence of this acid.

The presence of this acid in cultures limited only the growth of this fungi but did not affect their survival, indicating that the strains are resistant to this substance. Culture color on the medium depended on the species of fungi, and within the same species may be a visible sign of reaction to altered environmental conditions.

\section{DISCUSSION}

Current studies indicate the participation of microorganisms in the decomposition of organic phosphonates which are active substances of pesticides. Due to the enzymatic activity of the microorganisms these substances do not accumulate in the soil as they can be used as an alternative source of nutrients - carbon, nitrogen and phosphorus. A new class of compounds with herbicidal activity that exceeds the activity of glyphosate are N-pyridylamino)methylebisphosphonic acids, represented by $\mathrm{N}$-(2-pyridylamino)methylenebisphosphonic acid. Fusarium and Aspergillus fungi have been reported in the literature for the decomposition and utilization of bisphosphonates as a source of phosphorus. So far, Fusarium, Cylindrocarpon and Aspergillus isolates have been tested for their potential to degradation of this acid. Among the soil fungi only Cylindrocarpon sp. XX and Fusarium oxysporum XVI were capable to grow in presence of $\mathrm{N}$-(2-pirydylamino)methylenebisphosphonic acid as an alternative source of phosphorus what shows its biodegradation (Krzyśko-Łupicka et al. 2002; Krzyśko-Łupicka and Sudoł 2016).

In turn, studies on the utilization of this compound using the Aspergillus niger has not produced satisfactory results (Krzyśko-Łupicka et al.1999). On the other hand, there is no information on similar abilities with regard to Penicillium strains. These fungi are commonly found in the soil easily adapting to changing environmental conditions thanks to the rich enzymatic activity and the ability of growing with nutrient deficiency. It has been shown that Penicillium notatum, Penicillium citrinum and Penicillium oxalicum are capable of growing on different structurally phosphonates using them as the sole source of phosphorus (Zboińska et al. 1992; Klimek-Ochab et al. 2006).

In the own studies in the presence of bisphosphonic acid, changes were observed in the structure and color of the mycelium of $P$. expansum, $P$. waksmanii and spore velocity and spore size depending on the availability of nutrients. In the case of the $P$. fumiculosum strain, 
chlamydospores were formed as a result of changes in food conditions, and deformed spores. Müller and Loeffer (1987) report that long-term environmental changes lead to a transition from primary to secondary metabolism. The external symptoms of this process are: formation of aerial mycelium, conidia or fruiting bodies or spores. In addition, modifications of the media led to a change in mycelium coloring and affected the ability to form dye diffusers to the substrate. Müller and Loeffer (1987) and Kwaśna et al. (1991) state that dyes are not only metabolic by products but also take part actively in enzymatic transformation of fungi. Little is known about the effect of substrate composition of the amount and intensity of dyes. The coloring of fungi is more intense in sugar-rich media. This is confirmed by the results of our own studies - three Penicillium strains in medium without an easily digestible source of sugar did not form dyes. However, their production was observed both in the deficiency and in the presence of an alternative source of nitrogen or phosphorus or nitrogen and phosphorus. They assumed yellow.

The fungi are capable of biodegradation of organophosphorus compounds mainly by using of them as an alternative source of phosphorus. However, it is known that the ability to dispose of bisphosphonates is a graft feature. None of the tested Penicillium strains were able to use bisphosphonate as a source of nutrients..

\section{CONCLUSION}

1. Tested Penicillium strains exhibited resistance to $\mathrm{N}$-(2-pyridylamine) methylenebisphosphonic acid, were not able to use this acid as an alternative source of nutrients and were not capable to its biodegradation.

2. The availability of nutrients in modified media influenced the phenotypic changes of the examined fungi, which resulted in the ability to produce dyes. In the presence of a bisphosphonate as an alternative carbon source none of the tested strains produced a dye. The all Penicillium strains in the presence of bisphosphonate as an alternative source of nitrogen and phosphorus produced a yellow dye which could be treated as a metabolic disorder of the examined fungi in the presence of this acid.

\section{REFERENCES}

Bujacz B., Wieczorek P., Krzysko-Lupicka T., Lejczak B., Kafarski P. 1995. Organophosphonate utilization by the wild-type strains of Penicillium notatum. Appl. Environ. Microbiol. 61, 2905-2910.

Drzyzga D., Forlani G., Vermander J., Kafarski P., Lipok J. 2017. Biodegradation of the aminopolyphosphonate DTPMP by the cyanobacterium Anabaena variabilis proceeds via a C-P lyase-independent pathway. Environ. Microbiol. 19(3), 1065-1076.

Forlani G., Kafarski P., Lejczak B. 1997. Mode of action of herbicidal derivatives of aminomethylenebisphosfonic acid. Part II. Reversal of herbicidal action by aromatic amino acids. J. Growth Regul. 16, 147-152.

Giberti S., Bertazzini B., Liboni M., Berlicki Ł., Kafarski P., Forlani G. 2017. Phytotoxicity of aminobisphosphonates targeting both $\delta 1$-pyrroline-5-carboxylate reductase and glutamine synthetase. Pest. Manag. Sci. 73(2), 435-443. 
Kafarski P., Lejczak B., Forlani G., Gancarz R., Torreilles C., Grembecka J., Ryczek A., Wieczorek P. 1997. Mode of action of herbicidal derivatives of aminomethylenobisphosphonic acids. III. Structure- activity relationship. J. Plant Growth Regul. 16, 153-158.

Klimek M., Lejczak B., Kafarski P., Forlani G. 2001. Metabolism of the phosphonate herbicide glyphosate by a non-nitrate-utilising strain of Penicillium chrysogenum. Pest. Manag. Sci. 57, 815-821.

Klimek-Ochab M., Raucci, G., Lejczak, B., Forlani G. 2006. Phosphonoacetate hydrolase from Penicillium oxalicum: Purification and properties, phosphate starvation-independent expression, and partial sequencing. Res. Microbiol. 157, 125-135.

Krzysko-Lupicka T., Gajda A., Dzygiel P. 1999. Activity of soil-borne fungal strains Aspergillus niger van. Tieghem to degrade (N-piradyloamino)methylenobisphosphonic acid. Abstract 51st International Symposium on Crop Protection. Gent, Belgium, 4 May, 1999, [b.w.], 182.

Krzysko-Lupicka T., Slupczynska M., Kinal S. 2002. The ability of selected strains Cylindrocarpon species to growth in presence of $\mathrm{N}$-(2-pirydyloamino)methylenobisphosphonic acid served as sole source of carbon or nitrogen or phosphorus or nitrogen and phosphorus, in: Chemical products in agriculture and environment. Ed. H. Gorecki, Z. Dobrzanski, P. Kafarski. Prague, CZECH-POL TRADE, 297-299.

Krzysko-Lupicka T. 2005. The effect of $\mathrm{N}$-(2pirydyloamino) methylenobisphosphonic acid on activity of soil microorganisms, in: Chemistry for Agriculture. Vol. 6. Development in production and use of new agrochemicals. Ed. H. Gorecki, Z. Dobrzanski, P. Kafarski. Prague, CZECH-POL TRADE, 863-868.

Krzysko-Łupicka T., Sudoł A. 2016. N-(2-pirydyloamino)methylenebisphosphonic acid as a sole source of a fungi Fusarium strains growing. J. Ecol. Eng. 17(4), 107-111.

Kwaśna H., Chełkowski J., Zajkowski P. 1991. Grzyby (Mycota). T. XXII. Sierpik (Fusarium). Flora polska. Warszawa, PAN, 1-138. [in Polish]

Lejczak B., Boduszek B., Kafarski P., Forlani G., Wojtasek H., Wieczorek P. 1996. Mode of action of herbicidal derivatives of aminomethylenobisphosphonic acids. I. Physiologic activity and inhibition of anthocyanin biosynthesis. J. Plant Growth Regul. 15, 109-113.

Müller E., Loeffer W. 1987. Zarys mikologii. Warszawa, PWRiL, 18-35, 69-111. [in Polish]

Obojska A., Berlicki L., Kafarski P., Lejczak B., Chicca M., Forlani G. 2004. Herbicidal Pyridyl Derivatives of aminomethylene-bisphosphonic acid inhibit plant glutamine synthetase. J. Agric. Food Chem. 52(11), 3337-3344.

Shushkova T., Ermakova I., Leontievsky A. 2010. Glyphosate bioavailability in soil. Biodegradation 21, 403-410.

Tétard-Jones C., Edwards R. 2015. Potential roles for microbial endophytes in herbicide tolerance in plants. Pest. Manag. Sci. 72, 203-209.

Zboińska E., Maliszewska J., Lejczak B., Kafarski P. 1992. Degradation of organophosphonates by Penicillim citrinum. Lett. Appl. Microbiol.15, 269-272.

Yu Q., Powles S. 2014. Metabolism-based herbicide resistance and cross-resistance in crop weeds: a threat to herbicide sustainability and global crop production. Plant Physiol. 166, 1106-1118.

Abstract. N-(2-pyridylamino)methylenobisphosphonic acid exhibits high herbicidal capability. In this we would like to examine its interaction with soil microorganisms. The aim of this study was to evaluate the ability of Penicillium strains to grow in the presence of $1 \mathrm{mM} \mathrm{N}-(2-$ -pyridylamino)methylenobisphosphonic acid as an alternative source of phosphorus, nitrogen or carbon. The pure fungal cultures have been grown in Czapek medium or modificated medium, at $25^{\circ} \mathrm{C}$ for $1-4$ weeks. The growth of fungi in full mineral $\mathrm{pH} 5.6$ and $\mathrm{pH} 4.0$ media was considered as controls, whereas the growth of fungi in medium without nutriment (carbon, nitrogen, phosphorus, nitrogen and phosphorus) was an absolute control. In our studies we determined: the kinetics of mycelial growth, fungi morphology, degree of degradation of 
$\mathrm{N}$-(2-pyridylamino)methylenobisphosphonic acid by spectrophotometric UV-VIS and changes of media $\mathrm{pH}$. Tested fungi did not use a $\mathrm{N}$-(2-pyridylamino)methylenobisphosphonic acid as an alternative source nutrition. In each of the modified growth medium, inhibition of mycelial growth was observed. However, no changes of the concentration of studied acid in medium was observed. Simultaneously, we noticed phenotypic changes of the fungi what indicate that the metabolic disturbances in the presence of acid. 